\title{
Biomedical Communication and the Reaction to the Queensland Childhood Lead Poisoning Cases Elsewhere in the World
}

\author{
JOHN C BURNHAM*
}

Beginning in the 1890s, physicians in Queensland began reporting cases of lead poisoning in children. Lead poisoning up until that time-and for a long time after-was primarily an occupational disease, and the appearance of plumbism in children was therefore unusual, to say the least. As John Thearle has pointed out, the specific local events that brought Queensland physicians to interest themselves in the subject of lead poisoning in children constitute a striking incident in the history of medicine. Beyond that story, however, is what happened to the published reports of those physicians in the history of world medicine. ${ }^{1}$

The Queensland experience suggests not only dimensions of the history of lead poisoning in children but shows how biomedical knowledge was-and was notcommunicated. Citation studies of biomedical publications confirm impressionistic evidence that writers in the medical literature tended to cite work from their own national medical publications, rather than using, in an even-handed way, what was available in the world. ${ }^{2}$ It is in this context of cultural provincialism that the fate of the reports from

\footnotetext{
* John C Burnham, Departments of History and of Psychiatry, Ohio State University, 230 W 17th Avenue, Columbus OH 43210-1367, USA.
}

I have most gratefully benefited from the support and assistance of many librarians, including those at The Ohio State University, at the National Library of Medicine in Bethesda, and at Yale University Medical Library, and I want to recognize especially the assistance of Brenda Heagney and her staff at the Royal Australasian College of Physicians library. A summary of this paper was presented at the meetings of the Australian Society of the History of Medicine in Darwin, 7 July 1997, where participants offered useful comments, for which, again, I am grateful, and I have had additional comments from Bryan Gandevia.

\footnotetext{
${ }^{1}$ Lorimer Dods, 'Some aspects of Australian pediatrics', Pediatrics, 1952, 10: $367-8$, places the work on the Queensland lead poisoning cases among the major accomplishments in Australian paediatrics. Michael John Thearle, 'Dr. Alfred Jefferis Turner, 1861-1947', MD thesis, University of Queensland,
}

1987. I am preparing a book-length history of the evolution of the syndrome of childhood lead poisoning. Meanwhile the history of the problem has been reviewed by Jane $\mathrm{S}$ Lin-Fu, 'Historical perspective on health effects of lead', in K R Mahaffy (ed.), Disease and environmental lead: human health effects, Amsterdam, Elsevier Science Publishers, 1985, pp. 43-63, which summarizes and contextualizes her previous publications on the subject, particularly Jane S Lin-Fu, 'Lead poisoning and undue lead exposure in children: history and current status', in H L Needleman (ed.), Low level lead exposure: the clinical implications of current research, New York, Raven Press, 1980, pp. 5-16. The specific literature on lead poisoning in children exists, of course, in a context of a very extensive literature on the history of lead poisoning in general.

2 John C Burnham, 'The transit of medical ideas: changes in citation of European publications in USA biomedical journals', Actas del XXXIII Congreso International de Historia de la Medicina, GranadaSevilla: 1-6 septiembre, 1992, Sevilla, Imprenta A Pinelo, 1994, pp. 101-12, cites relevant literature. 
Queensland can best be understood. And yet in an exception that illuminates the way in which knowledge travelled, some of the work from Australia-work that had elements that were not just clinical observations-did, as will become clear, enter the world biomedical literature appropriately and in a timely way.

\section{An Epidemic of Lead Poisoning among Children}

The first report of lead poisoning in children in Queensland appeared in the transactions of the Intercolonial Medical Congress of Australia, meeting in Sydney in 1892. Additional reports followed. J Lockhart Gibson and other staff of the Brisbane Hospital for Sick Children decided that, beginning in 1890 , they had seen ten cases of lead poisoning in children. The main differential signs that they used were the slow onset of muscular dysfunction and the development of foot drop, which a few European observers had noticed as characteristic of children, in contrast to the wrist drop found characteristically in adults. The chief text to which they could refer was a recent article by an American neurologist in a cyclopedia of diseases of children. ${ }^{3}$

Why, Gibson and his colleagues asked, had this affliction suddenly appeared in Queensland? Indeed, the first case was not diagnosed as lead poisoning because the idea just never occurred to anyone as a possibility. Among physicians in Brisbane, lead poisoning was known as an occupational disease, among "painters, compositors, \&c." But there was no collective experience with non-occupational lead poisoning, such as that from drinking water, much less such an affliction in children. ${ }^{4}$

Miss Gillette, the matron at the hospital, thought that the source of the lead might be the foil in which the children's sweetmeats were wrapped. The children were known to chew the foil into balls and throw them at their playmates. "All the boys do it", noted one

\footnotetext{
${ }^{3} \mathrm{~J}$ Lockhart Gibson, et al., 'Notes on leadpoisoning as observed among children in Brisbane', Intercolonial Medical Congress of Australasia, Transactions, 1892, pp. 76-83. It was ironic that, despite a common belief that wrist drop was not typical of lead poisoning in children, that symptom was what first directed attention to the possibility of lead poisoning in the Queensland children. See Thearle, op. cit., note 1 above, p. 78 , which contains a complete narrative of Turner's involvement in the cases. See also John Thearle, Four pioneers in public health in Queensland, Sydney, The Royal Australasian College of Physicians, 1987. The cyclopedia article was J J Putnam, 'Toxic affections from arsenic and lead', in John M Keating (ed.), Cyclopedia of the diseases of children, medical and surgical, 5 vols, Philadelphia, J B Lippincott Company, 1890, vol. 4, pp. 599-642, an article that was based almost entirely on the literature and to only a very slight extent on clinical experience (apparently chiefly a family, including children, suffering from the effects of lead in the drinking water).

${ }^{4}$ According to A G Cumpston, 'Health and disease in the Broken Hill mining industry', an
}

offprint in the historical library, Royal Australasian College of Physicians, from the book, Broken Hill mines, 1968, there had been in fact one case, that of a two-year-old girl, which was among the few lead poisoning deaths recorded in connection with mining at Broken Hill in the period 1889-1891. She was the "child of the manager of block 14, who was believed to have been poisoned from a habit she had of picking flowers bearing the visible particles of flue dust which had fallen on them from the smelter stack under the shadow of which she lived". It was known that dogs, cats, and fowl in the area all suffered casualties close to the smelters. By 1897 , new regulations had greatly reduced the plumbism in connection with the Broken Hill works. But as late as 1902 , it was believed by the health officer that water drained from roofs poisoned "the general population", who were urged always to use water obtained from the water company; Legislative Assembly. New South Wales. Board of Health. (Papers Respecting Allegations Made Against the President of, In Connection with His Report on Lead-Poisoning at Broken Hill), 4 December 1902. 


\section{The Reaction to the Queensland Childhood Lead Poisoning Cases}

patient. Three samples of the foil did show lead content, but most did not, and the physicians remained unconvinced that the foil was the culprit. Nor could they identify any other source of the lead. ${ }^{5}$

Gibson and his colleagues later believed that they were the first to confirm that lead poisoning produced symptoms distinctively different in children from those typical in adults-particularly the distribution of paralyses. ${ }^{6}$ One of the physicians, A Jefferis Turner, the resident medical officer at the Hospital for Sick Children who saw the first patient and suggested that lead poisoning was a possibility, reported that the diagnosis was met with much scepticism in the medical community. But thereafter he and Gibson were able to diagnose increasing numbers of cases of lead poisoning in children, to the point that Turner in 1897 concluded that "when any child of from five to eight years of age in Brisbane suffers from convulsions, in the absence of any discoverable cause lead should be thought of as a possible source of the trouble". 7

Turner went on to explain what such a case was like, quoting from his notes on a case from Gympie seen in 1895:

Child lies on face, embracing pillow with both arms. When pain comes on[,] the head is thrown back by spasmodic contraction of the back muscles, muscles of arm are in tonic spasm, legs flexed, hamstrings forcibly contracted, legs tender, the slightest touch causing the child to cry out; the abdomen is not tender, and stands firm pressure well. Mind is perfectly clear; the child is very intelligent. This condition lasted several days. The previous day it had been worse, the child screaming with pain. ${ }^{8}$

Meanwhile, Gibson added a special emphasis that came to mark observations of the Queensland cases: ocular neuritis. In 1892, Turner had reported five cases of what he and Gibson supposed was "basal meningitis", on the basis that "paralysis of the sixth nerves depended on organic disease in or near the base of the brain". By 1897, Gibson and Turner had decided that they had really seen another set of cases of lead poisoning (in part because all the victims had recovered, which would not have been expected in cases of meningitis). Gibson was convinced that ocular neuritis was an important sign because, in 1896, two lead poisoning victims had shown that affliction but not other symptoms of lead poisoning. (By this time the medical staff was able more regularly to conduct chemical tests to detect lead in the urine. $)^{9}$

Also in 1897, a paper appeared that introduced another theme that persisted in the Queensland cases. T E Green, resident medical officer at the Hospital for Sick Children, in reporting additional cases, noted the possibility that lead had damaged the kidney in the

\footnotetext{
${ }^{5}$ Gibson, et al., op. cit., note 3 above, especially pp. 79, 83. Some of the victims were girls, not boys.

${ }^{6}$ Clinicians found that the famous blue line in the gum, so characteristic of chronic poisoning in the adult, was not often present in children. Throughout the history of lead poisoning in children, clinicians disagreed about characteristic symptoms, and lead poisoning in general was considered for generations to be one of the most refractory diagnoses in modern medicine.

${ }^{7}$ A Jefferis Turner, 'Lead-poisoning among Queensland children', Australas. med. Gaz., 1897, 16: 475-9. Thearle, op. cit., note 1 above, p. 76,
}

describes how Turner modestly deferred to Gibson in assigning credit for the diagnosis.

${ }^{8}$ Turner, op. cit., note 7 above, p. 476.

${ }^{9}$ See especially ibid.; A Jefferis Turner, 'A form of cerebral disease characterised by definite symptoms, probably a localised basic meningitis', Intercolonial Medical Congress of Australasia, Transactions, 1892, pp. 98-100; J Lockhart Gibson, 'Ocular neuritis, simulating basal meningitisplumbism', Australas. med. Gaz., 1897, 16: 479-82. That latter paper was phrased in so argumentative a way as to suggest that Gibson's conclusions were at best controversial. 


\section{John C Burnham}

fatal case of a girl of eleven years. While the main interest in the case was the discovery that there had been lead in the drinking water, the idea of nephritis was now present among clinicians in the area. ${ }^{10}$

By the last years of the 1890s, physicians associated with the Hospital for Sick Children-and no doubt other colleagues-were fundamentally concerned with the question of why they were seeing so many cases of children who apparently were suffering from plumbism-described by Turner as a preventable cause of "a large amount of suffering, disablement, blindness, and death". ${ }^{11}$ In a typical case, he reported,

The child is brought because it complains of headache, perhaps accompanied by vomiting. It is observed to have a slight squint, which is found to depend on paresis of one, or perhaps both external recti. Optic neuritis, often intense, is found to be present. In such a case the first diagnosis to be considered is lead-poisoning; the prognosis is favourable as regards life, but doubtful as regards vision.

And in many cases, he noted, tumours and meningitis were the likely mistaken diagnoses. $^{12}$

Gibson, Turner, and their colleagues in Queensland did not conceptualize lead poisoning in children as a special syndrome. Rather, they viewed the symptoms in children as a variety of lead poisoning in general. ${ }^{13}$ They posited a pathology that was not different from that in adults with occupational plumbism. In children, typical susceptibilities caused the symptoms to differ somewhat from those in adults. The range of symptoms was so great in both adults and children, however, that the most a clinician could say was, for example, "lead-palsy in childhood presents certain peculiarities in its distribution, which differ from the common, and typical, form of the disease in the adult". ${ }^{14}$ The fact that the term childhood, rather than children, was used, underlined the assumption that lead poisoning was a core constant, and the developing organism simply showed somewhat different manifestations of the constant: "the symptoms of this condition in childhood differ in some details from those met with in adults, on which the text-book descriptions appear to be exclusively based". ${ }^{15}$

\section{A Source for the Lead}

Early in the twentieth century, the history of Queensland children diagnosed with lead poisoning took a new turn. Gibson continued his crusade to connect ocular neuritis with lead poisoning in children, but he also believed that he had finally discovered the source

\footnotetext{
${ }^{10} \mathrm{~T}$ E Greene, 'Some unusual forms of lead poisoning', Australas. med. Gaz., 1897, 16: 483-4. The theme is traced, in context, in Richard $\mathrm{P}$ Wedeen, Poison in the pot: the legacy of lead, Carbondale, Southern Illinois University Press, 1984, pp. 164-74.

11 Turner, op. cit., note 7 above, p. 479.

${ }^{12}$ See especially A Jefferis Turner, 'How to recognise lead-poisoning in children', Australas. med. Gaz., 1899, 18: 425-7, pp. 425-6.

${ }^{13}$ See especially J Lockhart Gibson, 'Plumbic neuritis', Australasian Medical Congress,

Transactions, 1905: 306-14, pp. 307-9. Nor was the
}

\author{
distinction made elsewhere in the world or in \\ Australia. When, for example, the first water supply \\ in Sydney came through lead pipes, there was no \\ special category of the danger to children; the \\ professor of chemistry at the University of Sydney in \\ 1854 found unsafe levels of lead in three-fourths of \\ the samples of drinking water he tested. David Clark, \\ “"More Than physick": Sydney's water supply \\ $1788-1888^{\prime}$, in Max Kelly (ed.), Essays in urban \\ history, Sydney University Press, 1978, pp. 55, 60. \\ ${ }_{14}^{14}$ Gibson, et al., op. cit., note 3 above, p. 76. \\ 15 Turner, op. cit., note 12 above, p. 425 .
}




\section{The Reaction to the Queensland Childhood Lead Poisoning Cases}

of the toxic material, a source that explained why the phenomenon of lead poisoning in children was peculiar to Queensland. Gibson and Turner succeeded in getting some attention for the new ideas about the cause of the Queensland epidemic, but their way of conceiving of the disease did not make headway in the medical literature of the rest of the world.

In 1904, Gibson reported that four children with strikingly similar symptoms had come under his care and set him again looking for the source of the lead. Starting out with the assumption that "the source of the lead is available to almost all Queensland children who live in towns" and that other children in the household showed signs of lead but no poisoning, Gibson reported additionally that the government chemist had eliminated the commonplace galvanized iron water tank as a likely source. Finally Gibson, sitting on his own verandah and observing that the white paint on the railing was powdery, hit upon the factor common to virtually all of the cases: the children were exposed to surfaces painted with lead paint, and typically the affected children were those who bit their nails or put their fingers in their mouths (an action already condemned socially as a bad habit). The paint was "in houses whose rooms have been painted, or at least whose verandah railings have been painted" and where there was either sticky new paint or older paint that would powder and come off on the fingers. As Gibson concluded,

Although not averse to leading a crusade against the semi-vandalism of covering the prettily grained pine linings of our houses with paint, I am glad to think that the apparent fact that most of the cases bite their nails or suck their fingers will give us help in at least preventing the frequently recurring attacks which the ordinary lead cases get ... I have until now been in the habit of saying to patients' parents, 'You had better avoid tank water for drinking purposes' .. I I shall henceforth, unless I am offered a better explanation, blame paint. ${ }^{16}$

Thearle, in recounting the incident and subsequent events, emphasizes the role of the principals in campaigns to prevent lead poisoning by restricting the use of lead paint and restricting the amount of lead in the paint in Queensland. Already in 1904, they succeeded in having lead paint forbidden in schools, but not until 1922 was there any general law concerning lead paint ("No paint containing more than five per centum of soluble lead shall be used or put within four feet from the floor or ground on the outside of any residence, hall, school, or other building to which children under the age of fourteen years have access, or on any veranda railing, gate, or fence"). And that law may not have been well enforced. Individual responsibility was the more certain recourse. Gibson in his practice even went so far as to apply splints to the arms of children who bit their nails so

\footnotetext{
$16 \mathrm{~J}$ Lockhart Gibson, 'A plea for painted railings and painted walls of rooms as the source of lead poisoning amongst Queensland children', Australas. med. Gaz., 1904, 23: 149-53. Lorimer Dods, 'Early paediatrics in the Antipodes', Med.' J. Australia, 10 June 1961: 845. R Elliott Murray, Plumbism and chronic nephritis in young people in Queensland, Glebe, NSW, Australian Medical Publishing Co., 1939, p. 48, credits a Dr Hopkins, reported in Australas. med. Gaz., 1899, 18: 119, with making the first suggestion, at a meeting of the Medical Society
}

\author{
of Queensland: "Dr. Hopkins believed that white \\ paint on fences, \&c., was a possible cause. He had \\ observed children's hands coated with this." And \\ Gibson was in fact present and made the next \\ recorded comment. But there is no evidence that \\ anyone paid any attention to this idea before \\ Gibson's announcement in 1904. See Jonathan Gillis, \\ 'Bad habits and pernicious results: thumb sucking \\ and the discipline of late-nineteenth-century \\ paediatrics', Med. Hist., 1996, 40: 55-73.
}




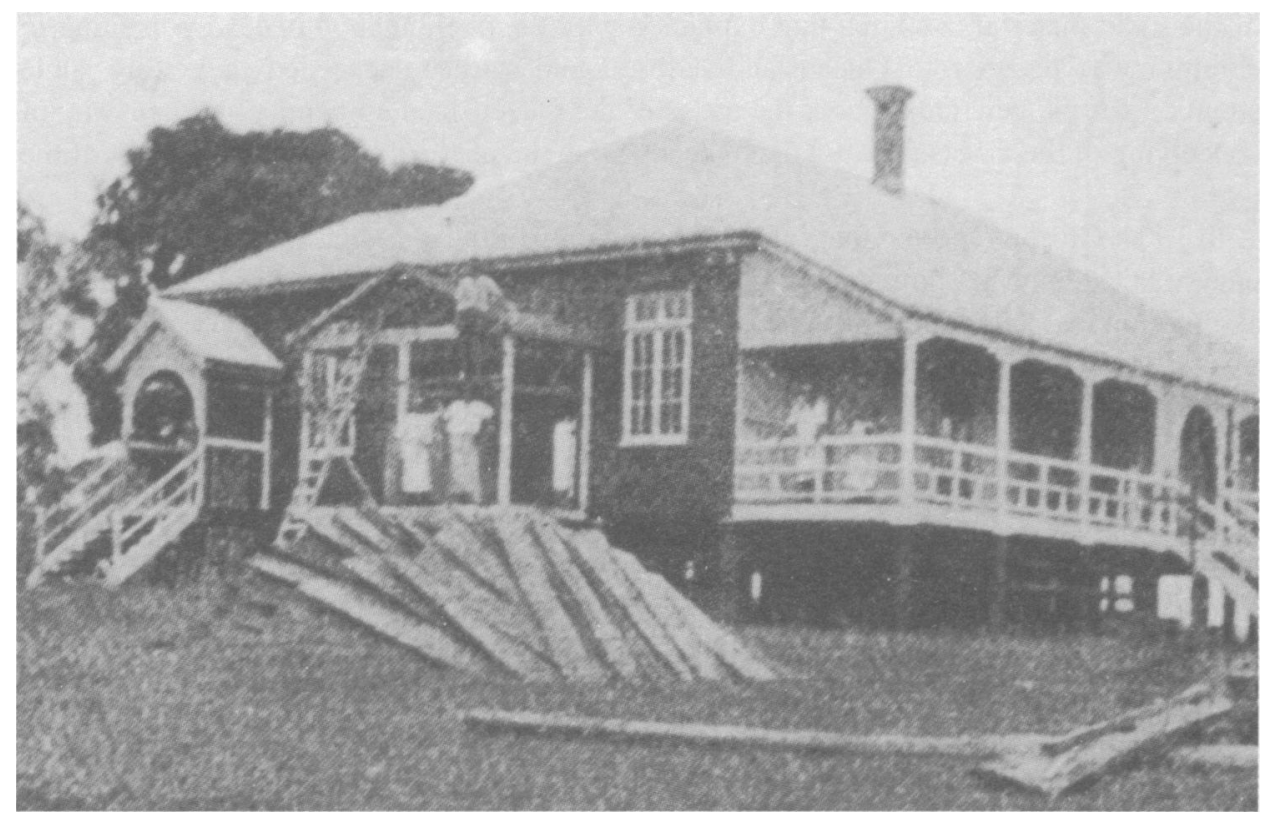

Figure 1: Typical Queensland house with painted verandah. This is reproduced from A Jefferis Turner's article on the Australian cases, in British Medical Journal, 1909.

that they could not carry the lead to their mouths. "This not only interrupts the habit", he observed, "but can be used as a very useful threat upon any tendency to its resumption". ${ }^{17}$

Within the Australian and even the Queensland medical community, however, at least into the 1930s, not all practitioners were convinced that lead poisoning came from painted verandahs. Indeed, some physicians were sceptical concerning "the existence of lead poisoning amongst Queensland children" at all-a not unreasonable scepticism, given the difficulty of diagnosing plumbism. The Queensland cases, in short, were not necessarily such clear-cut examples of lead poisoning as they appeared to later generations to be. ${ }^{18}$

\footnotetext{
${ }^{17}$ Thearle, op. cit., note 1 above, especially pp. 95 , 98. J Lockhart Gibson, 'Plumbic ocular neuritis in Queensland children', Br. med. J., 1908, ii: 1488-90, p. 1488. A publication, giving a good review and summary of the Queensland experience, appeared as background to the 1922 legislation: 'An historical account of the occurrence and causation of lead poisoning among Queensland children', Med. J. Australia, 11 February 1922: 148-52, probably written by Turner. Acts of the Parliament of Queensland, Session of 1922, XII, Part 1, p. 10023. See the account of the campaign by the physicians in Queensland in Report of the New South Wales Board of Trade on white lead as used in the painting industry: its dangers and their prevention, Sydney, William Applegate Gullick, Government Printer, 1921, pp. 697-8.

18 The author of 'An historical account', op. cit., note 17 above, in 1922 repeatedly referred to
}

scepticism and opposition regarding both the diagnosis and the source of the lead, and A Jefferis Turner, 'Experiences in preventive medicine,' Med. J. Australia, 12 November 1938, 2: 805-13, pp. $807-8$, recalled the opposition. By the 1930 s, the issue tended to revolve around epidemiological evidence vs. "scientific evidence", that is, laboratory evidence, a conflict that was commonplace still generations later. See Eustace Russell, 'The treatment of chronic nephritis', Med. J. Australia, 16 September 1933: 386; Eustace Russell, in Med. J. Australia, 2 December 1933: 774; L J Jarvis Nye, in Med. J. Australia, 28 October 1933: 608; J Lockhart Gibson and A Jefferis Turner, in Med. J. Australia, 23 December 1933: 865. There were of course other overtones, such as the sometimes unpopular political stances of the new advocate of the idea of widespread lead poisoning, Nye. 


\section{The Reaction to the Queensland Childhood Lead Poisoning Cases}

\section{The Fate of the Queensland Reports}

There is, however, a story beyond what happened in Australia, namely, what happened in other countries. Did physicians elsewhere utilize the reports that came out of Queensland? And that question breaks down into two further questions. Did physicians elsewhere hear about the reports, and, if so, what did they make of those reports?

The record was, in fact, entirely negative for many years. Neither in the few French or German articles about lead poisoning in children, nor in the equally scant Englishlanguage literature, did the work of the Australian physicians of the 1890s receive any notice or recognition. Typical was the survey published in 1900 by Gustav Hahn of Bischofteinitz. He assembled from the world's medical literature all the cases he could find reported of lead poisoning of children (42 individual cases, and another group of 42). But he was apparently entirely unaware of the Queensland cases. ${ }^{19}$

In 1907, David Edsall of the University of Pennsylvania, writing in a seven-volume survey of modern medicine edited by William Osler, did utilize the reports from Australia. Citing the Australasian Medical Gazette for 1897, 1899, and 1904, Edsall referred repeatedly to "the recent reports of Turner and Gibson of wholesale poisoning in the Queensland children", which Edsall attributed to lead in water tanks [sic]. The Queensland cases were notable for "some of their clinical features", Edsall continued, and he thought the occurrence of lead poisoning in children might often not be recognized. Citing the work of Putnam and others, Edsall asserted that "Plumbism in infancy and early childhood commonly shows such wide clinical divergence from that in adults that a brief separate mention of it is demanded". While Edsall noted conflicting evidence about the susceptibility of the young, he was able to cite the work of the Australians particularly in distinguishing a typical clinical picture somewhat different from that of adults: in diagnosis, Edsall recommended considering in children especially convulsions, colic, cramps, peripheral paralyses, rigidity of the neck, and ocular symptoms. But Edsall still considered the disease in children basically lead poisoning, merely with "wide clinical divergence from that in adults". ${ }^{20}$ Moreover, his recognition of the Queensland publications was virtually unique for many years. And writers on the subject of lead poisoning in children did not customarily cite Edsall's article, either.

In the face of this massive indifference to their reports, Gibson and Turner themselves undertook to publicize their findings beyond Australian publications. As early as 1908, Gibson published a report in the British Medical Journal, and a year later, in 1909, Turner did the same. These articles had the potential of bringing their work to the attention of not only the British medical world but, given the circulation of that journal, of readers in many countries who probably would not have had access to Australian publications. And, in

\footnotetext{
${ }^{19}$ [Gustav] Hahn, 'Encephalopathia saturnina bei einem 13monatlichen Kinde durch Hebrasalbe. Tod', Archiv für Kinderheilkunde, 1900, 28: 172-86. Examples of authors who did not cite the Queensland cases would include Allen Baines, 'Two cases of fatal lead poisoning', Archs Pediatrics, 1900, 17: 665-70; Friedmann, 'Ein Fall von akuter Bleiintoxikation im Säuglingsalter', Der Kinder-Arzt, 1901, 12: 73-5; G Variot, 'Paralysie des mémres inférieurs chez un garçon de huit ans', Gazette des
}

hôpitaux [Paris], 1902, 75: 482-4; and G Meillère, Le Saturnisme: étude historique, clinique et prophylactique, Paris, Octave Doin, 1903.

${ }^{20}$ David L Edsall, 'Chronic lead poisoning', in William Osler (ed.), Modern medicine, its theory and practice, in original contributions by American and foreign authors, 7 vols, Philadelphia, Lea Brothers, 1907 , vol. 1, pp. 84-113, especially pp. 87, 91, 105, and $107-8$. 
fact, Gibson noted in his article, "I have seen no reference to my work in any English or American publications except Osler's System". ${ }^{21}$

It is true that some of the papers from Queensland were listed in the standard bibliographical guides of that time. Those using the U.S. Surgeon General's catalogue could have found in the second series volume published in 1904, which contained an entry for lead poisoning in children, entries for Turner's 1897 and 1899 papers. The third series volume, which was not published until 1928, listed Gibson's 1917 paper emphasizing ocular involvement and Turner's paper from the British Medical Journal of 1909. The Index Medicus carried entries for Turner's 1897 paper and for Gibson's 1904 papers but otherwise would not have been very useful in locating Australian material. At least a handful of American libraries, for which we have some later records, contained the Australian journals in which the articles appeared, but it is unlikely that Americans outside of a few big cities, even had they used the indexes, would have had access to the journals (because summary records exist, I use the Americans as representative of overseas availability). ${ }^{22}$

There is good reason to believe, therefore, that Edsall's reference was the only nonAustralian reference for many years, and Gibson's frustration with failing to receive recognition is understandable (it is of course not possible at this time to reconstruct why Turner received more listings than Gibson, or why some papers were listed and others were not). It was a tribute to Edsall's wide reading that he did mention the work, but the Queensland cases were just not taken up elsewhere until 1914, when an isolated instance of lead poisoning in a child occurred in the United States.

At that time, a young paediatrician, Kenneth Blackfan, and a neurologist, Henry $M$ Thomas, both at Johns Hopkins, where Osler had taught until 1905, reported this single case of a boy of five with what they diagnosed as lead meningitis. Noting the rarity of reports of lead poisoning in children, they this time overlooked Turner and wrote that "J. Lockhart Gibson has for a number of years repeatedly called attention to a most remarkable group of cases seen in children of Queensland, Australia. The case which we have reported seems closely allied to these. In that country children in general seem peculiarly liable to lead-poisoning, and perhaps especially to its effects on the eyes". They went on to describe Gibson's idea that children get "dried paint from the railings of longpainted verandas or garden fences on their hands and then into their mouths". Gibson, they noted, recommended lumbar puncture "as the essential therapeutic measure" but apparently did no examination of the withdrawn fluid. With all of the evidence, Thomas and Blackfan drew the conclusion, parallel to that of Turner and Gibson many years earlier, that lead poisoning might mask itself as "serous meningitis". 23

\footnotetext{
${ }^{21}$ Gibson, op. cit., note 17 above, pp. 1488-90. The reference to Osler's System simply referred to a British variant title of Modern medicine. A Jefferis Turner, 'On lead poisoning in childhood', Br. med. J., 1909, i: 895-7. See John Burnham, 'The British Medical Journal in America', in W F Bynum, Stephen Lock, and Roy Porter (eds), Medical journals and medical knowledge: historical essays, London, Routledge, 1992, pp. 165-87.

${ }^{22} \mathrm{I}$, of course, used the Union list of serials.
}

\footnotetext{
${ }^{23}$ Henry M Thomas and Kenneth D Blackfan, 'Recurrent meningitis, due to lead, in a child of five years', Am. J. Dis. Child., 1914, 8: 377-80. The diagnosis that later generations of physicians would have made would have been encephalopathy, not meningitis. Some of the context is described in Elizabeth Fee, 'Public health in practice: an early confrontation with the "silent epidemic" of childhood lead paint poisoning,' J. Hist. Med. allied Sci., 1990, 45: 570-606.
} 


\section{The Reaction to the Queensland Childhood Lead Poisoning Cases}

Over the next two decades, Blackfan by himself, followed by other Americans at or from Johns Hopkins, sporadically attempted to establish a paediatric syndrome of childhood lead poisoning. They continued to be concerned (and with good reason) that cases of meningitis and encephalopathy and even convulsions caused by lead would be misdiagnosed. But they also came to believe that they had discovered a distinctive paediatric syndrome, not just a difference in symptomatology. Once alerted by Thomas and Blackfan, American writers, at least, did occasionally cite not only Gibson's and Turner's but some of the continuing reports from Australia. In 1917, Blackfan writing by himself noted that "We are indebted to the Australian writers Gibson, Love, Turner, Breinl and Young and others for much of the recent literature regarding lead poisoning in children", including 76 cases in five years. But of course Blackfan was already interested in portraying plumbism in children as a significantly distinctive syndrome worthy of consideration by physicians. ${ }^{24}$

\section{An Exotic Phenomenon}

One major reason that physicians outside Australia did not respond to the continuing virtual epidemic in Queensland was a universal assumption that the phenomenon-as reported-was localized and was, in fact, determined by geography. And this assumption of exceptionalism persisted even after leaded paint, particularly on verandahs, was identified as the source of the toxic lead.

As early as 1905, after he had pinpointed the painted verandahs, Gibson referred to "climates where conditions making children liable to lead-poisoning obtain". In 1908, he declared that "I am satisfied . . . that cases cannot be very infrequent in warm climates, other than Queensland, where sources of the poison similar to those pointed out in this paper are available". ${ }^{25}$ The problem was, of course, that there just were no reports of comparable cases from any other regions whatsoever, tropical or otherwise.

In fact, until 1914, all the cases were reported by physicians practising in Brisbane (although the patients were often referred in from various locations outside the city). Then in that year, A Breinl and W J Young reported cases from Townsville (1370 kilometres north of Brisbane). Following the lead of the Brisbane clinicians, Breinl and Young found a substantial number of cases (in one year, 18 of 22 patients examined had lead in their excreta). Breinl and Young raised a number of questions, however, about the conclusions that their colleagues had drawn. Breinl and Young fed two monkeys white lead paint and observed no untoward results, which caused them to suggest that the lead might be inhaled rather than ingested. "It is striking", those authors concluded,

that cases similar to those described above should not have been recorded from other parts of the tropics where lead paint is employed. Whether this be due to local conditions prevalent in Queensland only, to the difficulty of diagnosis, or to the lack of a definite clue associating such symptoms with lead, remains to be seen.

\footnotetext{
${ }^{24}$ Kenneth D Blackfan, 'Lead poisoning in children with especial reference to lead as a cause of convulsions', Am. J. med. Sci., 1917, 153: 877-87, especially 877 . Other examples include Charles F McKhann, 'Lead poisoning in children, with notes on therapy', Am. J. Dis. Child., 1926, 32: 386-92,
}

and L Emmett Holt, Jr, 'Lead poisoning in infancy', Am. J. Dis. Child., 1923, 25: 229-33, who cited Australian studies for the special symptoms of children, including ocular involvement.

${ }^{25}$ Gibson, op. cit., note 13 above, p. 307 . Gibson, op. cit., note 17 above, p. 1488. 


\section{John C Burnham}

Clearly, scepticism about all the information available up until then was appropriate. But one basic assumption persisted: that geography limited the incidence of the peculiar outbreak in tropical Queensland. And, in fact, Breinl and Young wrote from the Australian Institute of Tropical Medicine and published the paper in The Annals of Tropical Medicine ${ }^{26}$

The work of Breinl and Young did begin to modify the assumption in the reports from Brisbane that children with lead poisoning showed a high percentage of ocular nerve involvement. But otherwise they reinforced the idea that the Queensland cases in the literature of that day appeared to be idiosyncratic and could be subsumed under the heading of some kind of special susceptibility to lead, presumably in a warm climate. ${ }^{27}$

In 1922, a Sydney children's specialist, E S Littlejohn, reported three cases. The first, a boy of four and a half years, was from Cairns and was "perfectly typical of many that we have had in the hospital from time to time from Queensland". After a long description of verandahs in Queensland, Littlejohn explained that "in New South Wales, on the other hand, the children play for the most part in the garden or yards or streets and only exceptionally on the verandahs". Moreover, he continued, the houses in the south did not have raised verandahs with railings and were in any event largely brick, not painted wood. ${ }^{28}$

Then Littlejohn went on to his other two cases. They did not come from the tropics. One was a girl of three, who had "sucked and bitten most of the paint off the lower part of the window sash and frame" over a period of weeks. The second was a boy of nine who actually ate some paint his father was preparing to use. These latter two cases Littlejohn treated as accidents and of interest because of diagnosis and treatment; he showed no awareness that overseas, in America, following Thomas' and Blackfan's publication, a few (very few) additional cases of quite young children who ingested paint had been reported and that three paediatricians, particularly Blackfan, were already beginning to sketch a syndrome with a new characteristic, that of the paint-gnawing child-exactly like Littlejohn's case of the three-year-old girl. Rather, Littlejohn illustrates the persisting idea prevalent in Australia, and articulated by Gibson himself as late as 1931: "It has been difficult for those practising in other parts of Australia to recognize the special conditions under which our children live, and the special facilities they have for ingesting lead". As a public health official wrote from Melbourne in the 1920s,

No other State appears to have attached importance to the question of lead poisoning (except Queensland), where attention has been directed to the problem in consequence of the attacks made by Drs. Turner and Gibson on the use of white lead for interior painting or for exterior painting in the case of wooden buildings. These two doctors have been conducting a campaign for the last twenty years with a view to proving that lead poisoning among children is much more frequent than is generally admitted and with a view to gaining recognition for the pathogenic theory advanced by Dr. Gibson. ${ }^{29}$

\footnotetext{
${ }^{26}$ A Breinl and W J Young, 'The occurrence of lead poisoning amongst north Queensland children', Ann. trop. Med. Parasitol., 1914, 8: 575-90.

27 Ibid.

${ }^{28} \mathrm{E} \mathrm{S}$ Littlejohn, 'Three cases of lead poisoning in children', Med. J. Australia, 15 July 1922: 63-5.

${ }^{29}$ Ibid. Thomas and Blackfan, op. cit., note 23 above. See, for example, Kenneth D Blackfan, 'Lead poisoning in children with especial reference to lead
}

as a cause of convulsions', Am. J. med. Sci., 1917, 153: 877-87, and McKhann, op. cit., note 24 above. J Lockhart Gibson, 'Ocular plumbism in children', Br. J. Ophthalmology, 1931, 15: 637-42. White lead: data collected by the international labour office in regard to the use of white lead in the painting industry, Geneva, International Labour Office, Studies and Reports, Series F (Industrial Hygiene), No. 11, 1927, p. 114; the health officer was not named. 


\section{The Reaction to the Queensland Childhood Lead Poisoning Cases}

Even within Australia, then, physicians continued to think of lead poisoning in children as a localized condition. It was, as S F McDonald put it in a 1931 survey of lead poisoning in that country, "almost entirely, so far as is known at present, confined to north-eastern Australia, from the northern rivers of New South Wales up". Moreover, another kind of epidemiological evidence, from elsewhere in the world, showed that lead poisoning in children increased in the warmer seasons, and sometimes even plumbism in workers seemed to have a seasonal element. This connection between hot weather and the incidence of lead poisoning continued for many years to reinforce the idea that climate played an important part in the incidence of plumbism in Queensland children. ${ }^{30}$

\section{New Factors in Perceptions of Australian Plumbism}

By the beginning of the 1930s, adult lead poisoning was, as elsewhere in the world, declining in Australia. Only an occasional case of plumbism in a child was still being reported, but the impression of the earlier literature persisted: in Australia, McDonald noted, the disease in adults was an industrial disease; in children, "a house disease". 31

Meanwhile, in the 1920s, research on lead poisoning of all kinds began to centre in the United States. German and British writers, on the very rare occasions on which they took up lead poisoning in children, did not mention the Australian literature. The one notable exception was an article by an Edinburgh physician, Edwin Bramwell, who in 1931 mentioned in passing that "the epidemic of lead poisoning in children reported by Lockhart Gibson of Brisbane in 1897" came from "sucking the fingers and biting the nails after contact with white lead paint"-but while finally recognizing the Australian experience, Bramwell amazingly ignored the conspicuous contemporary American literature. ${ }^{32}$ An extensive series of cases from Japan also appeared in the literature, beginning in the 1920s, and the Australian cases were sometimes paired with the unexpectedly large amount of lead poisoning that occurred among children in Japan (the cause in Japan was usually lead cosmetic powders used by mothers). ${ }^{33}$

\footnotetext{
${ }^{30}$ See, for example, Keith D Fairley, 'A review of the evidence relating to lead as an aetiological agent in chronic nephritis in Queensland', Med. J. Australia, 5 May 1934: 600-6, p. 602; and D O Shiels, 'Industrial lead poisoning in relation to climate', Australas. Ann. Med., 1955, 4: 178-82. S F McDonald, 'Chronic lead poisoning', Med. J. Australia, 9 May 1931: 572-5, especially p. 575. Strangely enough, in their article that introduced experimental evidence suggesting that exposure to sunlight would increase the amount of lead absorbed in the body, Milton Rapoport and Mitchell I Rubin, 'Lead poisoning: a clinical and experimental study of the factors influencing the seasonal incidence in children', Am. J. Dis. Children, 1941, 61: 245-55, did not mention the Queensland cases.

${ }^{31}$ McDonald, op. cit., note 30 above. See, for example, 'Lead poisoning checked in Australia', Engng Min. J., 1931, 132: 488-90. Australian
}

physicians also made contributions to knowledge about occupational lead poisoning, but that work is beyond the limits of this paper.

${ }^{32}$ See, for example, Eduard Friedberg, 'Zur Klinik der chronischen Bleivergiftung im Kindesalter', Archiv für Kinderheilkunde, 1922, 71: 25-30. Edwin Bramwell, 'Some clinical pictures attributable to lead poisoning', Br. med. J., 1931, ii: 87-92, p. 87.

Florence A Brous, Bibliography and survey on lead poisoning, with particular reference to packaging, [New York], The Packaging Institute, 1943, is a comprehensive bibliography of the medical literature available.

${ }^{33}$ Some of this literature was reviewed in Katsuji Kato, 'Lead meningitis in infants', Am. J. Dis. Child., 1932, 44: 569-91, who did notice the work from Australia. See, similarly, Miriam Bell, 'Lead poisoning in children: a case report from Canton', China med. J., 1930, 44: 885-90, p. 886. 


\section{John C Burnham}

Just after 1930, medical publications on lead poisoning in children increased greatly all over the world. One major reason was a finding from the United States, that $\mathrm{X}$-rays of bone growth revealed a special diagnostic sign in children. Moreover, other innovations in diagnosis greatly heightened interest in plumbism, and all these advances together were used by the paediatricians in their attempt to establish a special syndrome. In the new literature, to which Australian writers contributed, the original Queensland cases continued to appear, but much more regularly now than they had in the decades after they were first reported-in part, of course, because this new generation of investigators and clinicians saw similarities between the earlier Australian experience and their own. ${ }^{34}$ Yet the citations often contained substantial distortions, particularly as Americans began to focus on children's chewing on painted surfaces as the source of toxic lead.

In 1934, for example, three members of the children's department of the London Hospital in England used the new x-ray technique to confirm a case, and in their introduction they noted that "In Queensland, Australia, the lead used in painting verandah railings is readily powdered by the hot dry atmosphere and has been reported as a cause of many cases of poisoning in children, since Gibson, Turner, and others drew attention to this danger some forty years ago". But after this nod in the direction of Brisbane, the authors centred their attention on the more recent American literature. ${ }^{35}$ In 1935, another English writer, Leonard Findlay, tried to amalgamate the Australian, Japanese, and American literatures into one general picture. Lead poisoning, he wrote, was an adult disease, but "in some countries, e.g., Australia and Japan, it seems to be not uncommon in childhood". 36

Nevertheless, by the 1930s, regardless of peculiarities of the western Pacific rim, the American reports dominated the world medical literature. Sometimes the Americans tended to forget the rest of the world, including Australia and Japan. And sometimes Americans conscientiously did try to include the Queensland experience-but at secondhand, evidently. F H Lewy of the University of Pennsylvania, for example, in 1939 in a curious misreading believed that "the heat and dryness in Queensland induced children to lick the cool surface of woodwork painted with white lead". Nor were other distant writers necessarily accurate, either: an editorial in the Lancet as late as 1949 referred to "the 'poisoned rain drops' on the white verandahs of Queensland houses". ${ }^{37}$

One of the striking developments in the dominant American literature was the emphasis on pica, or perverted appetite. In the United States, physicians portrayed lead poisoning in children as an accidental side effect of gnawing or chewing painted surfaces. In 1947, George Cooper, Jr, of the Hospital of the University of Virginia tried to place the Australian reports in this context: "In Queensland, Australia, numbers of children were poisoned by lead paint used on verandahs and other outdoor woodwork, due to inhalation of lead dust as well as to ingestion of the paint. In the hot, dry climate of Queensland, the

\footnotetext{
${ }^{34}$ See, for example, A J Lanza, 'Epidemiology of lead poisoning', J. Am. med. Ass., 1935, 104: 85-7, pp. 85-6.

35 T Stanley Rodgers, J R S Peck, and M H Jupe, 'Lead poisoning in children', Lancet, 1934, ii: 129-33.

${ }^{36}$ Leonard Findlay, 'Lead poisoning in the infant and young child', Post-Grad. med. J., 1935, 11:
}

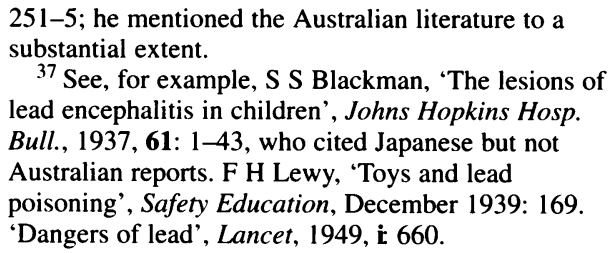

251-5; he mentioned the Australian literature to a substantial extent.

${ }^{37}$ See, for example, S S Blackman, 'The lesions of lead encephalitis in children', Johns Hopkins Hosp. Bull., 1937, 61: 1-43, who cited Japanese but not Australian reports. F H Lewy, 'Toys and lead poisoning', Safety Education, December 1939: 169. 'Dangers of lead', Lancet, 1949, ì 660. 


\section{The Reaction to the Queensland Childhood Lead Poisoning Cases}

paint was quickly reduced to a powder dangerous to children with healthy appetites as well as to those suffering from pica". A report from England as late as 1951 also tried to fit the Australian cases into the pica mould:

In children up to about 5 years the ingestion of lead paint or metallic lead due to perverted appetite is the most likely cause, although peculiar circumstances have resulted in large outbreaks in Queensland ... Climatic conditions there favoured the powdering of paint, which was readily transferred to the children's mouths. ${ }^{38}$

One of the reasons that Australia had tended to drop out of the medical literature was that the epidemic of the years at the turn of the century in fact did not continue. Indeed, by the 1930 s, cases of childhood lead poisoning were a rarity everywhere in Australia. By 1947, McDonald of Brisbane could comment, "It is a remarkable experience that in one's medical lifetime a grave disease has disappeared, and disappeared for no certain reason. Yet this is the case with lead poisoning in children in this city . . . today a case of lead poisoning is a clinical curiosity". 39

Australians attributed the waning of lead poisoning to a number of factors, especially education and medical awareness and, not least, the changes in paints used in the state. At least by the 1930s, whenever a child's birth was registered in Queensland, the mother was given a copy of a book of advice in which a whole page was devoted to the danger of lead paint on verandah railings. ${ }^{40}$

\section{Provinciality in Medicine}

I have been emphasizing the ways in which provinciality in the medical literature led to attention to the Queensland cases in the Australian and to some extent the Anglophone literature but also led to neglect among non-Australian medical writers. The record does make the Queensland childhood lead poisoning cases a good illustration of the operation

\footnotetext{
${ }^{38}$ George Cooper, Jr, 'Epidemic of inhalation lead poisoning with characteristic skeletal changes in children involved', Am. J. Roentgenology and Radium Therapy, 1947, 58: 130. N F Elliott

Burrows, John Rendle-Short, and Denis Hanna, 'Lead poisoning in children; report of five cases with special reference to pica', Br. med. J., 17 February 1951, i: 329.

${ }^{39}$ S F McDonald, 'Looking backward: a quartercentury of paediatrics. III: Juvenile lead poisoning', Med. J. Australia, 14 September 1946: 373-9, p. 373. D Clark Ryan, 'Acute accidental poisoning in children: its incidence, diagnosis and treatment', Med. J. Australia, 24 November 1951: 702-8, found only one lead case in 1024 poisonings in the Brisbane Children's Hospital in 1946-1949. The analysis of factors is summarized and discussed in Murray, op. cit., note 16 above, pp. 48-51. Lorimer Dods, 'Lead poisoning', Med. J. Australia, 8 June 1946: 816 , reported one of the rare cases: a boy of four years with lead poisoning attributed to "chewing his lead soldiers”. In 1953, for example, from
}

Melbourne, Ann Bridge, 'Lead intoxication in three families', Med. J. Australia, 11 July 1953: 62-5, reported poisoning of children and also adults who with "a poor standard of hygiene" suffered from particles generated by a nearby casket factory. Clearly interest in childhood lead poisoning continued in Australia, and not just in Queensland; see, for example, Ronald Freeman, 'Chronic lead poisoning in children: a review of 90 children diagnosed in Sydney, 1948-1967', Med. J. Australia, 28 March 1970, 1: 648-51.

${ }^{40} \mathrm{~L} \mathrm{~J}$ Jarvis Nye, Chronic nephritis and lead poisoning, Sydney, Angus \& Robertson, 1933, p. 114; I did not find information about when various formal warning practices were instituted. And I am, of course, not dealing with any developments in the last thirty years of the twentieth century; see, for example, Brian Lee, 'Lead risk to Australian children', New Scientist, 26 July 1979: 270, and Graham Vimpani, 'Could your young patient have lead poisoning?' Aust. Fam. Physician, 1995, 24: 1446-53. 
of cultural nationalism among twentieth-century clinicians and investigators alike. ${ }^{41}$ Certainly Gibson and Turner had to struggle to win recognition for their work not only outside Australia but even outside Queensland.

Their difficulties were not unique. Another, and largely contemporary, instance in which Australians' work from early in the twentieth century did not receive recognition in foreign biomedical writings was pink disease, or acrodynia. In this chronic condition, children's hands and feet turned red, and a panopoly of lamentable additional symptoms appeared. After 1945, pink disease increasingly was understood to be mercury poisoning, the cause and course of which in many ways parallels lead poisoning. In the 1920s, clinicians in America and Europe discovered the syndrome of pink disease independently, for a long time without acknowledging the work of Australian clinicians in describing the disease. As in the case of lead poisoning, only much later did non-Australian writers refer to the pioneer work done so far away. ${ }^{42}$

But in the instance of the two special themes introduced with the Australian cases of childhood lead poisoning, ocular and nephritic damage, it may be that, in the end, the world medical literature did not reflect national cultural factors nearly so strongly.

Ocular involvement never established itself in the literature. As noted above, from the first cases that he saw, Gibson received an impression that children poisoned by lead frequently showed ocular affections, sometimes paralysis of the external recti, sometimes amblyopia. Although Edsall from America and some Australian writers correctly mentioned this finding, most other medical writers did not mention this work even when taking up rare cases of ocular involvement in a poisoning case. As late as 1931, Gibson was pleading for recognition of his discovery, not only abroad but in Australia itself. In publishing in the British Journal of Ophthalmology, he noted, "Although I have written on this subject in Australia, I have only published one paper in England . .."43

\footnotetext{
${ }^{41}$ See, for example, the attempt of $\mathrm{H} \mathrm{G}$ Rischbieth, 'Lead poisoning', Clin. Reps Adelaide Children's Hosp., 1948, 1: 125-33, pp. 125-6, to place the work of Turner and Gibson in the world history of knowledge about lead poisoning. Much later, non-Australians from time to time did allude to the early Queensland experience, citing it in obligatory legitimizing background material that documented the scholarly credentials of the writer and the fact that investigations into lead poisoning had a venerable past; see, for example, Robert A Kehoe, 'The Harben lectures, 1960: the metabolism of lead in man in health and disease', J. R. Inst. Publ. Health Hyg., 1961, 24: 177-203, p. 184.

42 Ann Dally, 'The rise and fall of pink disease', Soc. Hist. Med., 1997, 10: 291-304. The clinical and geographical aspects are emphasized in Desmond $\mathrm{L}$ Gurry, 'The enigma of pink disease', in Suzanne Parry (ed.), From migration to mining: medicine and health in Australian history, Casuarina, NT, Historical Society of the Northern Territory, 1998, pp. 190-200. The parallels of the history of pink disease to childhood lead poisoning, such as the later
}

\author{
decline in incidence in Australia, are striking. \\ ${ }^{43} \mathrm{~J}$ Lockhart Gibson, 'Ocular plumbism in \\ children', Br. J. Ophthalmology, 1931, 15: 637-42, \\ especially 637 ; Gibson did not cite any publications \\ other than his own that would indicate support for \\ his views. His work was not cited, for example, in \\ Leopold Heine, Die Krankheiten des Auges im \\ Zusammenhang mit der inneren Medizin und \\ Kinderheilkunde, Berlin, Springer, 1921. See, for \\ example, Kato, op. cit., note 33 above, pp. 581-2, \\ where some Japanese literature is noted but without a \\ reference to the Australian. The great classic that \\ thrust American research into the forefront of \\ investigation of lead poisoning in general, Joseph $\mathrm{C}$ \\ Aub, et al., Lead poisoning, Baltimore, Williams \& \\ Wilkins, 1926, p. 213, actually cites Gibson's work, \\ noting sceptically that "certain authors, such as \\ Lockhardt [sic] Gibson of Australia ... insist that the \\ effects of lead on the eye are not very rare". The \\ citation is the more notable because Aub et al. did \\ not suggest that the cases were those of childhood \\ lead poisoning but only of lead poisoning in general.
}


By contrast with the fate of the idea of ocular involvement, which did not flourish in the literature, the early observations that lead poisoning affected the kidneys had a continuing history in which generations of Australian clinicians and investigators helped make the long-lasting effects of lead poisoning a substantial consideration in the later pictures of chronic renal insufficiency. In addition to articles, two monographs on the subject appeared in Australia, one in 1933 and one in $1939,{ }^{44}$ and eventually this Australian literature was cited overseas, as investigators continued into the last half of the twentieth century to test the connection between lead poisoning and nephropathy. ${ }^{45}$

Despite some clinical impressions, it was only in 1928 that D Gifford Croll and L J Jarvis Nye confirmed anecdotal evidence and called attention to the remarkably high rate of mortality from nephritis in Queensland-from three to five times, they believed, that of the other states in Australia. Once again, then, the northern state was exceptional. These findings stimulated a government inquiry, completed in 1932, that led Nye and others to conclude that childhood lead poisoning was a major factor in a very large number of later deaths from chronic nephritis. ${ }^{46}$

Slowly, overseas medical writers recognized the Australian contributions suggesting a connection between renal pathology and childhood lead poisoning-even in cases in which the work was cited as unconfirmed. And as the Australian contributions became more substantial, so did the overseas citations-just as they did also within the larger Australian medical community. By 1940, at least in this one small area of medical publication, Australians had become conspicuous in the mainstream. ${ }^{47}$

\footnotetext{
${ }^{44}$ Nye, op. cit., note 40 above, and Murray, op. cit., note 16 above. Damage to the kidney had long been a standard part of the pathology of lead poisoning; where the Australians were contributing was in emphasizing their idea that there were serious effects on the kidneys long after apparent recovery of the young patient.

${ }^{45}$ Although ironically as late as 1996 when compared to an American series from 1923 to 1966, the Australian cases still were perceived as exceptional, and Jill A McDonald and Nancy Upp Potter, 'Lead's legacy? Early and late mortality of 454 lead-poisoned children', Archs environ. Health, 1996, 51: 115-21, had to conjecture why the profile of their Massachusetts cases did not fit that of the well-established Australian cases-most strikingly in the area of kidney disease. Wedeen, Poison in the pot (op. cit., note 10 above), dealt with this problem and supposed that the Australians' conclusions would be confirmed.

${ }^{46}$ See Nye, op. cit., note 40 above (the figures are from pp. 1-2), and the later summary of D A Henderson, 'The aetiology of chronic nephritis in Queensland', Med. J. Australia, 22 March 1958: 377-86. See also Fairley, op. cit., note 30 above, pp. $600-6$, and the analysis of Murray, op. cit., note 16 above, who also places the findings in the context of general medical knowledge about the association of lead poisoning and kidney damage. I am not taking up the problem of age distribution that those investigators identified at the time.
}

\author{
${ }^{47} \mathrm{~J}$ A Inglis, D A Henderson, and B T Emmerson, \\ 'The pathology and pathogenesis of chronic lead \\ nephropathy occurring in Queensland', J. Pathol., \\ 1978, 124: 65-76, summarized the work for a British \\ and presumably world public. See, for example, \\ 'Plumbism and chronic nephritis', J. Am. med. Ass., \\ 1939, 113: 1503; Elvira Goettsch and Howard H \\ Mason, 'Glycosuria in lead poisoning', Am. J. Dis. \\ Child., 1940, 59: 119-28; Paul Reznikoff, 'Lead \\ poisoning', Am. J. Nursing, 1942, 42: 1123-6, p. \\ 1125; R K Byers, 'Lead poisoning: review of the \\ literature and report on 45 cases', Pediatrics, 1959 , \\ 23: 592; and Ronald E Lane, 'Health control in \\ inorganic lead industries', Archs environ. Health, \\ 1964, 8: 246-7. As late as 1957, Joseph C Aub (Aub \\ to William S Spector, 21 May 1957, Joseph C Aub \\ Papers, Countway Medical Library, Boston, USA) \\ was aware of work tending to confirm Nye's \\ findings, although Aub believed that "If it ever \\ occurs in the United States, it must be very rare \\ indeed". In 1963, an attempt to replicate the \\ Queensland findings of renal disease using records of \\ Massachusetts children diagnosed with plumbism \\ was a resounding and baffling failure; Lloyd B \\ Tepper, 'Renal function subsequent to childhood \\ plumbism,' Archs environ. Health, 1963, 7: 76-85. \\ Sometimes, of course, even in this special area, \\ Australian work was not mentioned, and early \\ examples include Beintker, 'Nierenreizung bei \\ frischer Bleivergiftung', Die medizinische Welt, \\ 1929, 3: 1292, and S S Blackman, Jr, 'Intranuclear
}




\section{John C Burnham}

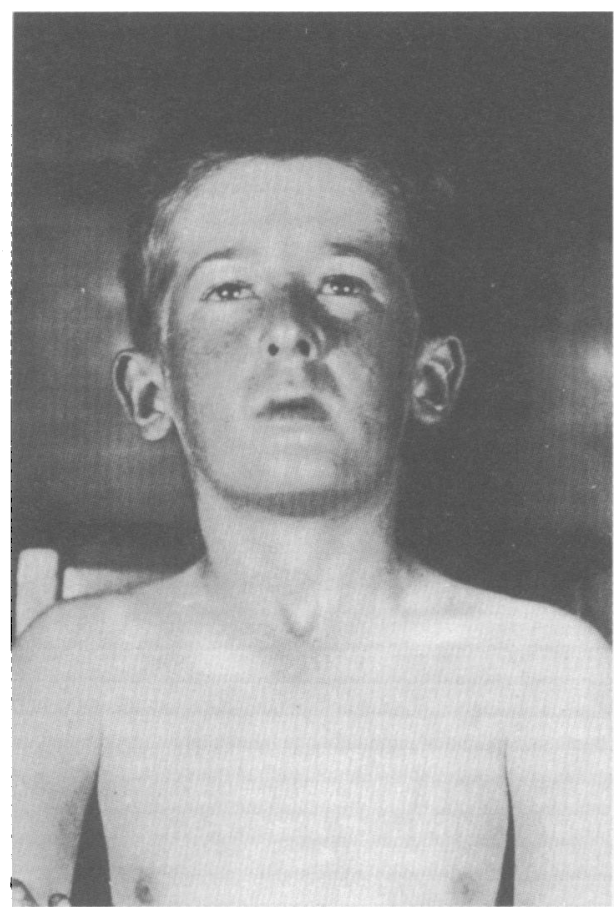

Figure 2: L J Jarvis Nye in 1933 used this photograph to suggest that lasting nephropathy followed ostensible recovery from childhood lead poisoning: "This typical child of fourteen years of age has a physique of about eleven years. The skin is dry and the whole appearance is typical of the 'azotaemic state'." Reproduced with the permission of HarperCollins from Chronic nephritis and lead poisoning.

It must have been frustrating through all the decades before 1940, however, that the physicians who collectively had the largest clinical experience with lead poisoning in children did not win comparable recognition overseas. In candid moments, they blamed themselves, as if they were the only ones in the world whose reports had had problems in the precision of diagnosis or use of laboratory techniques. ${ }^{48}$

From a much later perspective, however, it is possible to observe that Queensland physicians could not have expected much recognition in any of the other national medical communities. Despite the normal orientation of Australians of an earlier day to Britain, the fact was that physicians in the UK took little or no interest in lead poisoning in children because virtually no cases were reported there, and many years passed when no cases at all were reported. Moreover, in the rare instances when cases did appear in Britain, the usual factor of provinciality cut in, despite the Anglophone ties, and Australian contributions were not recognized. ${ }^{49}$ Continentals, too, seldom reported childhood lead

inclusion bodies in the kidney and liver caused by lead poisoning', Johns Hopkins Hosp. Bull., 1936, 58: 384-98.

${ }^{48} \mathrm{See}$, for example, Murray, op. cit., note 16 above, pp. 32-3.

\footnotetext{
${ }^{49}$ See, for example, Norman S Clark, 'Lead poisoning in infancy', Archs Dis. Child., 1950, 25 : 297-301, p. 297; J G Millichap, K R Llewellin, and R C Roxburgh, 'Lead paint: a hazard to children', Lancet, 1952, ii: 360-2.
} 


\section{The Reaction to the Queensland Childhood Lead Poisoning Cases}

poisoning, and they even more seldom mentioned the Australian reports. ${ }^{50}$ Americans, for their part, eventually constructed their interpretations of childhood lead poisoning, as has been noted, around the idea of pica, and lead poisoning was secondary to that disease in children who chewed painted surfaces. The Queensland youngsters who merely bit their nails or sucked their fingers never did fit into this picture easily.

What particularly emerged was the striking geographic provincialism of all physicians in the temperate zones. The " "poisoned rain drops' on the white verandahs of Queensland houses" or just paint that weathered in a tropical climate was simply too exotic a phenomenon to enter the discourse of medicine in non-tropical, but dominant, medical centres. As the British team of 1951 phrased it, "peculiar circumstances" existed in Queensland. ${ }^{51}$

\section{Can Biomedical Science Surmount Cultural Nationalism?}

McDonald in 1946 wrote one conclusion to the story of, as he put it,

Gibson's fight for lead-free paint and his efforts to teach the evils of nail-biting; but the strange thing remains that, without his being successful in either effort, the disease has disappeared . . . its history remains-the history of a brilliant piece of research of a type which it is nowadays the fashion to label somewhat slightingly as merely "clinical". 52

It may be that clinical medicine will always be subject to the provinciality of regional and national medical communities. But when laboratory and epidemiological evidence came into play, Australians, in the case of plumbism in children in Queensland, may have found that they could enter the world biomedical literature on a more equal basis. And, indeed, another Australian research, the Port Pirie (South Australia) Cohort Study, carried out over several years and focused on the subject of children's intelligence, also entered into the world-or at least American-biomedical literature (the question of the effects of childhood plumbism on IQ was in the last decades of the twentieth century an American preoccupation). ${ }^{53}$

The instance of lead poisoning in children in Queensland therefore suggests that cultural nationalism may not have had a uniform effect in shaping the ways in which writers in the medical literature monitored the literature. ${ }^{54}$ It may be that, in the twentieth century, members of a regional or national medical community paid more attention to

\footnotetext{
${ }^{50}$ For an example of obvious ignoring of Australian literature, see Beihefte zum Jahrbuch für Kinderheilkunde, 1925, vol. 6.

${ }^{51}$ As late as 1963, Tepper, op. cit., note 47 above, speculated at length about the climatic peculiarities that differentiated cases in Queensland. See, for example, John M Hunter, 'The summer disease: an integrative model of the seasonality aspects of childhood lead poisoning,' Soc. Sci. Med., 1977, 11: 691-703, who opened his article with a short account of the Queensland experience.

52 McDonald, op. cit., note 39 above, p. 374.

${ }^{53}$ Peter A Baghurst, et al., 'Environmental exposure to lead and children's intelligence at the age of seven years,' New England J. Med., 1992, 327: 1279-84.
}

\footnotetext{
${ }^{54}$ One of the major means of communicating in medicine was by personal travel and visitation. In the case of lead poisoning in children, at least up to 1950 , there was no evidence that international conferences or travel, even trips to England that would not have been unusual for professionals in Australia, played any role in carrying ideas or alerting clinicians. This is the more remarkable in that very many Australian physicians were trained in Britain and maintained professional ties with British colleagues. (Turner, op. cit., note 18 above, pp. 805-13, for example, returned to Britain repeatedly and even once, in 1917 , travelled by way of Indianapolis.)
} 


\section{John C Burnham}

clinical reports, like those of Gibson, from within their own community, while laboratory and epidemiological reports moved more easily from one culture to another. The sense of Gibson and Turner and other Australians that they had difficulty gaining recognition for their work in the larger world of medicine was no doubt accurate. But eventually some of this work won more recognition than other work, despite national cultural differences. ${ }^{55}$

55 The Norwegians, under similar circumstances, even, and apparently successfully, devised programmes with emphases that would maximize the world impact of their biomedical research efforts; see
Øivind Larsen (ed.), The shaping of a profession: physicians in Norway, past and present, Canton, MA, Science History Publications, 1996. 